\title{
Dampak Keberadaan Pondok Pesantren Terhadap Perkembangan Ekonomi Masyarakat: Studi Kasus di Pondok Pesantren Ulil Al Baab NW Gegek Lombok Timur
}

\author{
Umiatul Fitriana \\ Universitas Hamzanwadi \\ umiatul.fitriana@gmail.com
}

\begin{abstract}
Abstrak
Penelitian ini bertujuan untuk mengetahui Sejarah dan perkembangan pondok pesantren Ulil Al Baab NW Gegek, keadaan masyarakat sekitar sebelum dan sesudah adanya pondok pesantren Ulil Al Baab NW Gegek dan dampak pondok pesantren Ulil Al Baab NW Gegek terhadap perkembangan perekonomian masyarakat. Jenis penelitian yang digunakan ialah penelitian kualitatif dengan metode deskriptif. Teknik pengumpulan data dalam penelitian ini ialah mengunakan teknik observasi, wawancara, dan dokumentasi. Analisis data menggunakan reduksi data, penyajian data, dan penarikan kesimpulan.Hasil penelitian ini menunjukkan bahwa pondok pesantren Ulil Al Baab NW Gegek merupaan pondok pesantren yang berada di dusun Gegek Desa Perian Lombok Timur. Pondok pesantren ini adalah lembaga pendidikan, sosial dan dakwah di bawah naungan organisasi Nahdatul Wathan. Pondok pesantren ini didirikan oleh TGH. Lalu Suparlan Ahmad pada tahun 1993. Adapun keadaan masyarakat sebelum adaya pondok pesantren yaitu, kurang memahami tentang keagamaan. Dampak pondok pesantren terhadap kehidupan sosial masyarakat adalah terciptanya budaya baru di dalam masyarakat yaitu, budaya salam. Dalam masalah perekonomian dampak pondok pesantren Ulil Al-Baab adalah terciptanya lapangan pekerjaan baru untuk masyarakat walaupun itu bersifat peribadi. Dengan adanya lapangan kerja baru itu bisa membatu masyarakat untuk melengkapi kebutuhannya dan meringankan permasalahan ekonomi masyarakat.
\end{abstract}

Kata Kunci: Pondok Pesantren, Ulil Al-Baab, Perekonomian, Masyarakat

\begin{abstract}
This study aims to determine the history and development of the Ulil Al Baab NW Gegek Islamic boarding school, the condition of the surrounding community before and after the existence of the Ulil Al Baab NW Gegek Islamic boarding school and the impact of the Ulil Al Baab NW Gegek Islamic boarding school on the economic development of the community. The type of research used is qualitative research with descriptive methods. The data collection technique in this research is using observation, interview, and documentation techniques. Data analysis used data reduction, data presentation, and drawing conclusions. The results of this study indicate that the Ulil Al Baab Islamic Boarding School NW Gegek is a boarding school located in the hamlet of Gegek, Perian Village, East Lombok. This Islamic boarding school is an educational, social and da'wah institution under the auspices of the Nahdatul Wathan organization. This Islamic boarding school was founded by TGH. Then Suparlan Ahmad in 1993. As for the condition of the community before the existence of the Islamic boarding school, namely, they did not
\end{abstract}


understand religion. The impact of Islamic boarding schools on the social life of the community is the creation of a new culture in society, namely the greeting culture. In economic problems, the impact of the Ulil Al-Baab Islamic boarding school is the creation of new jobs for the community, even though it is personal. With the new job opportunities it can help the community to complete their needs and alleviate the community's economic problems.

Keywords: Islamic Boarding School, Ulil Al-Baab, Economy, Society

\section{Pendahuluan}

Pendidikan di artikan sebagai salah satu bagian kegiatan kebudayaan, sebagai proses regenerasi, pendidikan sebagai contoh sehngga suatu bangsa siap secara jasmani dan ruhani melanjutkan kehidupan yang lebih baik. Sejarah pendidikan di Indonesia sebenarnya sudah lama dimulai sebelum hari pendidikan nasional, sebalum penjajahan, mengiringi proses agana-agama besar dunia. Bangsa kita memiliki tradisi pendidikan yang dikelola oleh masyarakat yang dipengaruhi oleh adat istiadat, tradisi, budaya, agama, dan kepercayaannya masing-masing (Rifa'i, 2011: 14).

Di Indonesia ada beberapa perbedaan pendidikan yang terjadi mulai dari pendiikan di masa klasik sampai pendiikan pada zaman penjajahan. Pendidikan masa klasik sering dikaitkan dengan zaman pra sejarah karena kerja meraka dalam menandai dan menemukan bukti peninggalan peradaban dan kebudayaan. Pendidikan di masa penyebaran Hindu Budha yang diutamakan adalah pendidikan keagamaan, pemerintahan, strategi perang, ilmu kekebalan, serta kemahiran menunggang kuda dan memainkan senjata tajam (Gunawan, 1986: 4-6). Pendidikan pada masa penyebaran Islam terbagi menjadi 3 jenis pendidikan Islam di Indonesia yaitu, pendidikan Langgar dengan pola pengajarannya dengan jalan, murid-murid diajarkan secara individual, yaitu menghadap para guru saru per satu. Pendidikan pesantren murid-murid yang belajar diasramakan dalam suatu kompleks yang dinamakan pondok (Rifa'i, 2011: 30-41).

Madrasah sebagai lembaga pendidikan dalam bentuk pendidikan formal sudah dikenal sejak awal abad ke-11 atau ke-12 M, atau abad ke-5-6 H, yaitu sejak dikenalnya madrasah Nidzamiyah yang didirikan di Baghdad. Di Indonesia madrasah merupakan fenomena modern yang muncul pada awal abad ke-20. Sebutan madrasah di Indonesia mengacu kepada pendidikan yang memberikan pelajaran agama Islam tingkat rendah dan menengah. Jika dilihat dari sejarah masuknya Islam di Indonesia, maka agama Islam dibawa oleh para pedagang-pedagang dari Gujarat yang disiarkan secara damai. Orang- 
orang yang kemudian masuk Islam ingin mempelajari dan mengetahui lebih lanjut tentang islam, disinilah mulai tumbuh pendidikan agama Islam, pada mulanya mereka belajar dirumah-rumah,dilanggar di masjid kemudian di Pondok Pesantren (Shaleh, 2004: 11$13)$.

Pesantren jika disandingkan dengan lembaga pendidikan yang pernah muncul di Indonesia, merupakan sistem pendidikan tertua saat ini dan dianggap sebagai produk budaya Indonesia yang indigenous. Pendidikan ini semula merupakan pendidikan agama Islam yang dimulai sejak munculnya masyarakat Islam di Nusantara pada abad ke-13. Beberapa abad kemudian penyelenggaraan pendidikan ini semakin teratur dengan munculnya tempat-tempat pengajian (Sulthon \& Khusnurdilo, 2008: 1). Pondok pesantren baru dikenal eksistensinya dan perkembangannya di Indonesia setelah abad ke16. Karya-karya jawa kelasik seperti serat Cibolek dan serat Centini mengungkapkan bahwa sejak permulaan abad ke-16 ini di Indonesia bahwa telah banyak dijumpai lembaga-lembaga yang mengajarkan kitab-kitab Islam klasik dalam bidang fiqih, aqidah, tasawwuf, dan menjadi pusat-pusat penyiaran Islam, yaitu pondok pesantren.

Di Lombok Timur khususnya di Desa Perian terdapat pondok pesantren yang bernama Pondok Pesantren (Ponpes) Ulil Al Baab NW Gegek. Ponpes ini sudah berdiri sejak 25 tahun silam. Disini terdapat kurang lebih dari 200 santri yang menimba ilmu pengetahuan khususnya dalam bidang agama. Dengan adanya santri disini tentu ini membuat perubahan baru bagi para warga, karena jika kita melihat sebelumnya bagaimana di dusun ini bisa dikatakan tidak berpenghuni sampai didirikannya ponpes ini. Datangnya para santri untuk menyantri disini yang membuat perbedan begitu banyak mulai dengan lebih banyaknya orang-orang sekitar yang tinggal di Gegek.

Pesantren tidak hanya sebagai wadah atau tempat proses belajar mengajar tetapi juga sebagai wadah kemandirian, belajar ekonomi. Pondok pesantren bukan hanya menguntungkan bagi para santri tetapi juga menguntungkan bagi masyarakat. Keberadaan pondok pesntren ini memiliki keuntungan yang besar bagi masyarakat sekita terutama di bidang sosial dan ekonomi. Di dalam bidang sosial bisa dilihat dari keberadaan penduduk sekitarnya yang mana sebelum keberadaan ponpes ini jumlah penduduk yang ada di sekitaran pondok pesantren tidak terlalau banyak mengingat disana masih sangat rawan atau berbahaya karena dikelilingi dengan hutan yang tentu memiliki resiko yang besar ketika menetap disana. Dengan keberaan pondok pesantren masyarakt 
berbondong-bondong membuat rumah atau tempat tinggal di sekitaran pondok pesantren. Seiring berjalannya waktu perkembangan dan kemajuan ponpes ini sangat pesat, hal itu bisa dilihat dari peningkatan jumlah santrinya yang kian meninggat setiap tahunnya. Semakin berkembangnya pondok pesantren maka semakin berkembang pula pemikiran masyarakat terutama dalam bidang perekonomian. Perkembangan perekonomian masyarakat semakin berkembang yang sebelumnya masyarakat hanya pengandalkan hasil sawah atau pertanian yang memiliki penghasilan yang kurang banyak, kemudian beralih untuk untuk memanfaatkan kebaradaan pondok pesantren dengan membuat mata pencaharian yang lain yang tentunya dapat menambah dan menjadikan perekonomian mereka semakin bertambah.

Pengembangan masyarakat adalah salah satu metode pekerjaan sosial yang tujuan utamanya untuk memperbaiki kualitas hidup masyarakat melalui pendayagunaan sumbersumber yang ada pada mereka serta menekankan pada prinsip partisipasi sosial. Pengembangan masyarakat merupakan suatu proses swadaya masyarakat yang tujuannya adalah untuk meningkatkan kondisi masyarakat pada bidang sosial, politik, kultural dan ekonomi. Sebagai suatu metode, pengembangan masyarakat menekankan adanya proses pemberdayaan, partisipasi dan peranan langsung dari warga komunitas. Istilah pengembangan masyarakat dapat berarti untuk beragam orang (Suharto, 2005). Pengembangan masyarakat dapat dipandang sebagai suatu proses, metode, program atau gerakan. Pengembangan masyarakat sebagai suatu proses bergerak dalam tahapantahapan dari suatu kondisi-kondisi atau keadaan tertentu ketahap berikutnya, yakni mencakup kemajuan dan perubahan dalam artian kriteria terspesifikasi.

Pengembangan masyarakat sebagai suatu metode merupakan cara untuk mencapai tujuan dengan cara sedemikian rupa sehingga beberapa tujuan dapat dicapai. Sebagai suatu program pengembangan masyarakat dinyatakan sebagai gugus prosedur dan isinya dinyatakan sebagai suatu daftar kegiatan. Program pengembangan masyarakat sebagai suatu gerakan merupakan suatu perjuangan sehingga menjadi alasan sehingga membuat orang-orang mengabdi. Pengembangan masyarakat dalam arti ini cenderung melembaga dan membangun struktur organisasinya sendiri, menerima prosedur dan praktisi profesional dengan demikian fokusnya adalah mendorong gagasan-gagasan pengembangan masyarakat (Yuliani, 2016). 
Penelitian terkait dengan pesantren dalam hubungannya dengan tingkat perekonomian masyarakat di sekitar pondok pesantren sudah banyak dilakuan. Penelitian tersebut menjadi salah satu referensi dalam melakukan penelitian ini dan menjadi alternatif baru dalam pengembangan ekonomi masyarakat di sekitar pondok pesantren. Penelitian-penelitian tersebut merupakan bukti bahwa masyarakat di sekitar lingkungan pondok pesantren terberdayakan dengan secara ekonomi (Reginald \& Mawardi, 2014; husmeru, Masrukin, \& Pangestuti, 2017; Rohmatun, 2013; Zaenurrosyid, 2018; Hafidh \& Badrudin, 2018; Syarbani, 2012). Oleh karena itu tujuan penelitian adalah untuk mengetahui sejarah dan perkembangan pondok pesantren Ulil Al Baab NW Gegek, mengetahui keadaan masyarakat sekitar sebelum adanya pondok pesantren Ulil Al Baab NW Gegek dan setelah adanya pondok pesantren Ulil Al Baab NW Gegek, dan untuk mengetahui pengaruh pondok pesantren Ulil Al Baab NW Gegek terhadap perkembangan perekonomian masyarakat.

\section{Metode Penelitian}

Penelitian ini merupakan penelitian kualitatif dengan pendekatan fenomenologi (Moleong, 2017). Metodologi kualitatif merupakan sebuah prosedur penelitian yang menghasilkan data deskriptif dari objek atau subjek yang telah diamati (Moleong, 2017: 4). Sumber data didapatkan melalui observasi, wawancara, dokumentasi, dan studi kepustakaan. Data ditemukan melalui observasi dimana peneliti mengamati secara langsung ke lokasi penelitian, khusunya yang menyangkut tentang sejarah, dan perkembangan pondok pesantren Ulil Al Baab NW Gegek. Mengamati keadaan masyarakat sebelum dan sesudah adanya pondok pesantren, dan dampak pondok pesantren terhadap perkembangan perekonomian masyarakat. Selanjutnya dilakukan wawancara dimana wawancara dilakukan dengan pendiri dan pimpinan ponpes Ulil Al Baab NW Gegek atau yang mewakili setelah adanya persetujuan dari pimpinan ponpes Ulil Al Baab. Dokumentasi dilakukan dengan cara mengumpulkan data yang diperlukan yaitu data yang diperoleh dari hasil wawancara, data dari kegiatan observasi, data profil ponpes dan Profil Desa Perian. Selain dokumen berupa data-data dari desa, peneliti juga mengambil data berupa foto tentang bagaimana kegiatan santri dan jenis-jenis usaha yang ada di masyarakat. Teknik analisis data yang digunakan adalah teknik analisis model 
interaktif. Analisis model interaktif meliputi tiga kompenen penting, yakni reduksi data, penyajian data, dan penarikan kesimpulan.

\section{Pembahasan}

\section{Profil Desa Perian Lombok Timur}

Desa Perian merupakan salah satu dari 8 (delapan) desa yang berada di sebelah utara Kecamatan Montong Gading Kabupaten Lombok Timur dengan luas wilayah 9,75 $\mathrm{km}^{2}$. Desa ini merupakan salah satu desa dengan tingkat pengaruh terhadap wilayah sekitarnya relatif cukup besar, baik dari aspek fisik, sosial maupun ekonomi. Kondisi ini disebabkan oleh faktor perkawinan. Dari aspek sosial, penduduk Desa Perian memiliki populasi penduduk yang tergolong cukup tinggi, karena Desa Perian tidak melakukan pemekaran seperti desa-desa lain di wilayah Kecamatan Montong Gading dengan jumlah Dusun sebanyak 10 dusun dan 46 RT. Jarak Desa Perian dengan Ibu Kota Kecamatan sekitar 4 km, dapat ditempuh sekitar 30 menit dengan menggunakan kendaraan bermotor, apabila ditempuh dengan jalan kaki sekitar 1 jam perjalanan. Sedangkan dari Ibukota Kabupaten desa ini berjarak sekitar $26 \mathrm{~km}$ dan sekitar $40 \mathrm{~km}$ dari Ibukota Provinsi. Untuk mencapai desa ini dapat menggunakan kendaraan bermotor maupun angkutan umum (Profil Desa Perian, 2019).

Menurut Data Profil Desa Perian per Juni tahun 2016, jumlah penduduk di Desa Perian tercatat 8.109 jiwa, dengan jumlah Kepala Keluarga 2.662 KK, yang terdiri atas laki-laki 4.010 jiwa dan perempuan 4.099 jiwa. Jumlah penduduk usia produktif sebesar 4.115 jiwa (50,7\%), terdiri dari 2.136 orang perempuan dan 1.979 orang laki-laki. Kelompok usia produktif tersebut saat ini 4.115 yang terdata sedang bekerja ke Luar Negeri sebagai BMI sebanyak 455 orang atau sebesar 10,8\% (425 laki-laki dan 30 orang perempuan). Selain itu diperkirakan 201 orang (186 orang laki-laki dan 15 orang perempuan) pernah menjadi BMI.

Tingkat pendidikan tersebut menunjukkan kualitas sumber daya manusia di Desa Perian. Artinya Jumlah penduduk yang telah mengenyam pendidikan sebesar 2.696 (33\%) orang dari 8.109 penduduk Desa Perian. Rendahnya tingkat pendidikan tersebut dipengaruhi oleh beberapa faktor, antara lain; 1) Terbatasnya lapangan kerja dan rendahnya upah di desa; 2) Makin menyempitnya lahan pertanian; 3) rendahnya kesadaran masyarakat entang pentingnya pendidikan; 4) anggapan masyarakat tentang 
pendidikan bahwa mengenyam pendidikan tinggi itu tidak menjamin masa depan karena walaupun sudah sarjana pun masih sulit mendapatkan kerja (menganggur).

Masyarakat Perian sebagian besar bermata pencaharian sebagai buruh tani dan petani. Selain itu peternakan terutama peternakan sapi merupakan pekerjaan yang banyak digeluti oleh sebagaian masyarakat Perian karena merupakan jenis pekerjaan yang punya prospek bagus untuk dikembangkan baik secara bisnis maupun peluang mengingat Perian memiliki tanah yang subur dan dekat dengan kawasan Taman Nasional Gunung Rinjani (TNGR). Masyarakat yang hidup berbatasan langsung dengan wilayah TNGR seperti, kekadusan Taer-Aer, Gunung Paok, dan Serijata memanfaatkan kawasan hutan untuk menananam dan mengambil rumput sebagai pakan ternaknya. Bahkan dari hasil pengamatan kami masyarakat Perian terutama yang berada di tiga wilayah kekadusan tersebut memiliki intensitas yang tinggi memasuki kawasan TNGR untuk mengambil hasil hutan bukan kayu (HHBK) terutama rumput. Di samping itu kotoran ternak sapi bisa juga dimanfaatkan sebagai pupuk kompos atau organik untuk pupuk tanaman pertanian.

Menurut data yang diperoleh di lapangan bahwa Dusun Pesisok adalah dusun yang paling banyak mengirimkan TKI. Sedangkan Dusun Gunung Paok, Serijata dan Taer-Aer adalah dusun yang berbatasan langsung dengan kawasan TNGR memiliki kontibusi pengiriman TKI yang tidak terlalu signifikan dibandingkan dengan dusun lain yang tidak berbatasan langsung dengan kawasan. Hal ini dipengaruhi oleh tingkat kesejahteraan warga di pinggir kawasan lebih baik dari yang lain karena warga juga memanfaatkan kawasan sebagai penopang ekonomi. Hal inilah yang harus bisa diarahkan dengan baik agar pengelolaannya tidak mengarah ke arah perusakan, tetapi ikut menjaga kelestarian lingkungan dengan cara warga juga dapat mengambil manfaat dari kawasan TNGR.

Pola kehidupan masyarakat Perian merupakan pencerminan sosial budaya yang di wujudkan dalam berbagai bentuk seperti, adat istiadat, gotong royong dan organisasi kesenian. Dalam sistem sosial budaya diharapkan adanya kepribadian dan kesadaran masyarakat yang mantap sehingga dapat dicegah nilai-nilai sosial budaya yang bersifat feodal dan terbelakang yang mudah dipengaruhi kebudayaan asing yang negatif. Dilain pihak perlu ditumbuhkan kemampuan masyarakat untuk menyaring dan menyerap nilainilai dari luar yang positif dan yang diperlukan bagi pembaharuan dalam proses pembangunan. 
Adat istiadat yang berkembang di desa Perian adalah adat Sasak karena memang penduduknya seluruhnya merupakan suku Sasak. Hal ini tercermin dari tata cara atau perilaku masyarakat yang menjalani kehidupan. Adat istiadat Sasak yang dijalankan tersebut merupakan warisan dan peninggalan nenek moyang penduduk tersebut yang sampai dewasa ini masih kuat. Sebagai contoh dapat dilihat upacara perkawinan yang dikenal dengan adanya selabar serta sorong serah.

Selain yang tersebut di atas, budaya yang masih menonjol adalah sifat gotong royong yang merupakan budaya yang telah lama berakar dalam setiap kehidupan masyarakat Sasak sejak dahulu. Hal ini menjadi pencerminan sekaligus perwujudan dari sila kelima yaitu, keadilan sosial bagi seluruh rakyat Indonesia. Dalam hubungan sosial, masyarakat Desa Perian berjalan kondusif. Selama ini tidak pernah ditemukan pertikaian yang cukup berarti antara warga. Sebab, antara warga terus dibentuk rasa kekeluargaan pada setiap lingkungan dengan membentuk berbagai perkumpulan seperti Karang Taruna, kelompok Ternak, Kelompok Tani.

\section{Sejarah Pondok Pesantren Ulil Al Baab NW Gegek Lombok Timur}

Pondok Pesantren Ulil Al Baab NW Gegek merupakan pondok pesantren yang berada di Dusun Gegek Desa Perian Kecamatan Montong Gading Kabupaten Lombok Timur. Pondok pesantren ini adalah lembaga pendidikan, sosial, dan dakwah yang berada di bawah naungan salah satu organisasi terbesar di Provinsi Nusa Tenggara Barat yaitu, organisasi Nahdlatul Wathan (Habib dan Zuhdi, 2014). Pondok pesantren ini didirikan oleh TGH. Lalu Suparlan pada tahun 1993 di Dusun Gegek (Data Yayasan Pondok Pesantren Ulil Albab, 2016).

Yang melatar belakangi berdirinya Yayasan Pondok Pesantren Ulil Al Baab NW Gegek adalah karena ada beberapa hal yaitu; 1) Adanya kesadaran masyarakat untuk mengamalkan ilmu agama yang bertujuan untuk meninggikan kalimat Allah SWT;2) Mencerdaskan bangsa serta dapat membekali generasi masa depan dengan iman dan taqwa dan ilmu pengetahuan agar dapat meminimalisir usaha-usaha yang digencarkan oleh para misionaris dan orientalis dalam rangka mengikis nilai-nilai Islam; 3) Tuntutan dan permintaan kaum masyarakat pada pendiri untuk mendirikan suatu wadah pendidikan yang bernuansa Islami namun dapat bersaing dengan dunia luar; 4) Turut serta mencerdaskan dan mensukseskan program pendidikan wajib belajar pemerintah 
(Wawancara, H. L. Budi Karyawan, 2 Mei 2019). Berdirinya pondok pesantren ini juga tidak terlepas dari peran masyarakat setempat yang menginginkan adanya lembaga pendidikan agama yang bisa memberikan ilmu agama dan keterampilan lainnya bagi anak-anak mereka.

Adapun juga yang melatar belakangi didirikannya Yayasan Pondok Pesantren Ulil Al Baab NW Gegek adalah adanya animo masyarakat secara sadar bahwa di era yang akan datang tidak akan sama dengan apa yang mereka hadapi sekarang ini. Untuk itu masyarakat menginginkan memiliki bekal yang kuat dalam menghadapi semua itu. Salah satunya mereka menginginkan anak-anaknya mahir di dua bahasa yakni bahasa Arab dan Inggris. Pada masa itu jika seseorang mau belajar bahasa Arab dan Inggris itu mereka harus pergi mondok ke Jawa yaitu, Gontor dan Ngabar. Untuk itu pimpinan pondok pesantren berinisiatif untuk membangun pondok pesantren yang menggunakan bahasa Arab dan bahasa Inggris sebagai bahasa pengantar santrinya (Wawancara, TGH. Lalu Suparlan, 5 Mei 2019).

Pada awalnya Yayasan Pondok Pesantren ini hanyalah sebuah pondok santri biasa, dimana santri/santriwatinya hanya tinggal di pondok, namun lembaga pendidikan formal mereka berada di luar pondok, salah satunya adalah SMA di Desa Perian dan juga di Desa Keluncing (Wawancara, H. L. Budi Karyawan, 2 Mei 2019). Sebagai sebuah pondok santri/santriwati pada awalnya, tentunya mempunyai mata pelajaran dan waktu belajar yang digunakan seperti pondok santri/santriwati lainnya. Di dalam pondok ini yang dipelajari dan diajarkan adalah diantaranya pelajaran Nahwu dan Sharof, Bahasa Arab, Bahasa Inggris, dan pelajaran ilmu agama lainnya.

Dalam perjalanannya, pondok santri ini tetap melakukan proses belajar mengajar dengan mengajarkan pelajaran bahasa Arab, Nahwu dan Sharof dari tahun 1990-1993, dengan metode pengajaran kholaqoh (duduk bersila). Kondisi pengajaran seperti ini dikarenakan pondok santri/santriwati tersebut belum memiliki fasilitas belajar yang memadai seperti lembaga pendidikan lainnya. Kegiatan-kegiatan yang dilakukan oleh para santri/santriwati dalam pondok yaitu bangun tengah malam pukul 03.00 Wita untuk sholat Tahajjud disertai dengan belajar dan membaca Al-qura'an sampai tiba waktu sholat Subuh. Setelah sholat Subuh selesai para santri melakukan latihan berbahasa Arab dan bahasa Inggris. 
Barulah pada tahun 1993, pimpinan Pondok Santri secara resmi membuka sebuah Yayasan Pondok Pesantren yang diberi nama Yayasan Pondok Pesantren Ulil Al Baab NW Gegek. Dengan mendirikan lembaga pendidikan pertamanya yaitu, lembaga pendidikan formal tingkat Madrasah Tsanawiyah (MTs) yang diberi nama MTs. Ulil Al Baab NW Gegek pada tahun 1997. Kemudian pada tahun 1998 pondok pesantren mulai menerima santri baru. Setiap pondok pesantren akan mengalami perubahan dan perkembangan setiap tahunnya, begitupun dengan Yayasan Pondok Pesantren Ulil Al Baab. Seiring dengan bertambahnya santri/santriwati yang datang dan masuk mendaftarkan diri menjadi santri/santriwati, maka yayasan inipun mengembangkan lembaga pendidikan yang dikelolanya agar dapat menampung santri/santriwati yang baru masuk maupun yang sudah tamat. Akhirnya yayasan inipun mendirikan sebuah lembaga baru lagi yaitu, lembaga pendidikan Sekolah Menengah Atas (SMA) Islam.

Selain lembaga pendidikan MTs. yang dibangun pertama kali, kini Yayasan Pondok Pesantren sudah memiliki beberapa lembaga pendidikan seperti; SMA Islam, Sekolah Menengah Kejuruan (SMK), Madrasah Ibtidaiyah (MI), Taman Kanak-Kanak (RA), Madrasah Diniyah Takmiliyah, Takhassus, Tahfidzul Qur'an. Di samping itu ada penunjang untuk Yaysan seperti, Pusat Kesehatan Pesantren (Pukestren), Waserda, Kopontren, LKSA/PA, LM3 Pertanian, TPKU Industri Konveksi dan percetakan sablon. Pondok pesantren sebagai lembaga pendidikan sekaligus sebagai proyek masa depan umat, maka harus bisa menunjukkan keseriusan dalam pengkaderan umat supaya lembaga ini bisa melakukan yang bermanfaat bagi kepentingan umat. Salah satu menunjukkan keseriusannya dalam pendidikan dimana di pendidikan formal dilakukan pemberdayaan terhadap guru-guru secara berkelanjutan. Pada pendidikan non formal seperti, diniyah, pihak pondok meningkatkan dan mengefektifkan pembelajaran diniyah untuk melihat titik kurangnya dimana dan sudah tercapai atau belum agar pihak pondok bisa mengevaluasi diri. Perbanyak musyawarah, diskusi atau sharing secara berkala untuk evaluasi tentang bagaimana mutu layanan terhadap santri (Wawancara, H. L. Budi Karyawan, 2 Mei 2019).

Pondok pesantren ini berdiri dari tahun 1993. Banyak faktor yang menjadikan pondok pesantren ini cepat berkembang seperti sekarang ini. Total santri sudah mencapai 725 orang (Data Yayasan Pondok Pesantren Ulil Al Baab NW Gegek 2019). Salah satu faktor pendukung yang sangat signifikan adalah output alumninya yang dilihat oleh 
masyarakat. Di samping itu tentunya kontribusi atau peran masyarakat yang berbentuk materi dan material kemudian moril serta dukungan masyarakat. Pondok pesantren Ulil Al Baab NW Gegek tentunya menjadi salah satu harapan masyarakat dan umat dalam mengembangkan agama, memajukan pendidikan. Untuk itu pihak pondok pesantren memiliki target setiap 5 tahun ke depannya. Target pondok pesantren ini yakni, menyesuaikan visi pondok pesantren yakni, "progresif, beda, dan unggul", agar terus menjadi garda terdepan dalam menghasilkan sumber daya manusia yang unggul di tengah-tengah suasana zaman modern.

Dalam konteks tersebut terkait pesantren, maka suatu pesantren dimaknai sebagai pendidikan dengan tujuan menanamkan keimanan dan ketakwaan kepada allah SWT, akhlak mulia serta tradisi pesantren untuk mengembangkan kemampuan, pengetahuan dan keterampilan peserta didik untuk menjadi ahli ilmu agama Islam atau menjadi muslimah yang memiliki keterampilan untuk membangun kehidupan yang Islami di masyarakat (Muhakamurrohman, 2014; Qomar, 2007). Seperti pendidikan yang berada di pondok pesantren Ulil Al Baab NW Gegek yang menyelenggarakan pendidikan dengan meningkatkan akhlak mulia itu bisa terlihat dari visi 5 tahun kebelakang yaitu pondok pesantren yang berakhlakul karimah (Wawancara, H. L. Budi Karyawan, 2 Mei 2019).

Setiap pondok pesantren pasti mempunyai kegiatan sehari-hari, mulai pagi sampai malam hari, adapun kegiatan di ponpes ini mulai dilakukan pada pagi hari mulai dari jam 03.00 mereka melakukan shalat tahajjud secara berjamaan dan iktiqaf sampai terbit fajar, setelah itu mereka melakukan aktifitas diluar pondok seperti sekolah. Mulai dari jam 02.00 mereka melakukan aktivitas serta rutinitas yang ada di pondok berupa diniyah, shalat berjamaah, dan lain-lain (Wawancara, TGH. Lalu Suparlan, 5 Mei 2019).

Ponpes ini memiliki keunggulan yang tentunya sangat berbeda dari pondok lainnya dimana santrinya benar-benar dibimbing dengan sebaik-baiknya. Meskipun di ponpes ini identik dengan pembelajaran masalah agama tetapi, di ponpes ini tidak hanya mengajarkan pengetahuan agama saja atau tentang akhirat melainkan mengajarkan tentang ilmu umum atau tentang dunia. Ini membuktikan dengan seringnya santri Ulil Al Baab ini mendapat penghargaan mulai dari tingkat bawah sampai tingkat provinsi. Banyak sudah santri ponpes ini yang dikirimkan ke luar negeri untuk menuntut ilmu misalnya di Mesir, Yaman, Kairo, dan lain-lain (Wawancara, H. L. Budi Karyawan, 2 Mei 2019). 
Ponpes Ulil Al Baab NW gegekadalah pondok pesantren yang sangat terkenal akan kedisiplinannya mulai dari bangun tidur sampai tidur lagi itu sudah diatur jadwalnya. Misalnya ketika bangun tidur santri diwajibkan bangun pukul 03.00 Wita dan langsung pergi ke masjid, santri baru pulang nanti pada pukul 06.00 Wita. Untuk santri dari MTs. langsung bergegas untuk membersihkan halaman dan jalan sekitaran pondok pesantren dan bagi santri yang SMA/SMK bergegas untuk pergi ke sekolah. Bagi siswa MTs. karena mereka masuk pada jam siang hari untuk pagi harinya diisi dengan kegiatan diniah dimana untuk diniah ini mereka mempelajari tentang agama. Ketika santri MTs. pergi ke sekolah baru santri yang sekolah di MA/SMK mengikuti kegiatan diniyah. Khusus untuk. Untuk hari Jum'at, Sabtu, dan Ahad, pembelajaran diniahnya diliburkan karena pada hari Jum'atnya bagi yang MTs. santri latihan seni bela diri (Karate). Sedangkan untuk hari Sabtu giliran siswa SMK latihan seni bela diri. Untuk hari Ahad latihan bersama mulai dari MTs., SMA dan SMK.

Di Ponpes ini bukan hanya dikenal dengan kedisiplinannya akan tetapi dikenal akan bahasanya yang mana mereka menggunakan 3 bahasa yaitu, bahasa Indonesia selama 6 bulan bagi santri ula (awalatau baru) sampai dia dilantik menjadi santri kudama' (lama). Kemudian mewajibkan berbahasa Inggris selama seminggu dan bahasa Arab selama seminggu bagi santri lama.

\section{Keadaan Masyarakat Sekitar Pondok Pesantren Ulil Al Baab NW Gegek}

Pembangunan manusia tidak hanya menjadi tanggungjawab pemerintah atau masyarakat semata-mata, tetapi menjadi tanggung jawab semua komponen, termasuk dunia pesantren. Pesantren yang telah memiliki nilai historis dalam membina dan mengembangkan masyarakat, kualitasnya harus terus didorong dan dikembangkan. proses pembangunan manusia yang dilakukan pesantren tidak bisa dipisahkan dari proses pembangunan manusia yang telah diupayakan pemerintah (Wahidah, 2015).

Lingkungan di luar pesantren dinamakan masyarakat, mereka mungkin bisa berada di sekitar lingkungan pesantren atau berada di wilayah lain dimana pesantren itu berada. Dimanapun pesantren itu berada maka sudah menjadi kewajiban untuk menjadi peduli pada kondisi masyarakat sekitarnya. Idealnya memang sebuah lembaga pondok pesantren memiliki upaya-upaya untuk mengembangkan masyarakat sekitar. Sehingga pada daerahdaerah yang terdapat pondok pesantren diwarnai oleh keberadaan pondok pesantren itu 
sendiri (Ulum, 2018). Pondok pesantren sebagai lembaga sosial, memiliki satu keunikan yang sangat berbeda dan tidak dimiliki oleh lembaga lain. Pondok pesantren mempunyai kesempatan dan kemungkinan besar untuk dapat berkifrah dan berperan pada penguatan masyarakat. Pondok pesantren menjadi pelofor perubahan di tengah- tengah masyarakat baik sosial, ekonomi dan buadaya (Sugandi, Tanjung, \& Rusli, 2017).

Sebelum berdirinya ponpes ini, masyarakat Gegek merupakan salah satu masyarakat yang kurang agamis, akan tetapi mereka telah mengenal ajaran agama dengan baik walaupun pada dasarnya pengetahuan ajaran agama mereka belum begitu mendalam. Peran pesantren sebagai lembaga pendidikan Islam telah lama dilaksanakan oleh institusi ini, namun sejalan dengan perkembangan, maka peran lembaga inipun meluas. Tidak hanya bergerak di bidang pendidikan saja, tetapi juga di bidang sosial masyarakat dan penyiaran agama, karena keberadaan pesantren biasanya berpengaruh langsung ataupun tidak langsung terhadap pembentukan watak masyarakat sekitar. Adapun manfaat sosial yang didapatkan dijelaskan oleh salah satu guru bahwa:

Manfaat sosial yang didapatkan setelah adanya pondok pesantren Ulil Al Baab NW Geek yaitu, orang-orang memiliki mata pencaharian yang lain misalnya mereka membuat warung, toko-toko dan lebih-lebih sekarang ada lembaga kesejahteraan anak (LKSA) lembaga kesejarteraan untuk panti jompo. Manfaat di sekitar pondok yaitu, untuk mensejahterakan masyarakat di sekitar (Wawancara, Saepudin, 3 Mei 2019).

Pondok pesantren Ulil Al Baab NW Gegek dalam pengaruhnya untuk merubah perilaku keagamaan masyarakat Gegek melalui beberapa upaya baik dalam bidang pendidikan, baik formal maupun non formal, dalam bidang dakwah melalui pengajian dan peringatan hari besar islam serta dalam bidang sosial sebagaimana yang diungkapkan oleh Kepala Dusun Gegek:

Pondok pesantren sangat memiliki peran besar terhadap masyarakat setelah adanya pihak pondok pesantren sering mengadakan pengajian setiap hari seperti rutinitas dan setiap bulannya dan isi dari pengajian tersebut tentunya tentang agama maupun yang lainnya. Darisana masyarakat sedikit mengetahui tentang agama dan tentang berbagai permasalahan umumnya karena tidak jarang di dalam pengajiannya di datangi ustaz ustaz dari luar pondok pesantren ataupun tamu-tamu dari luar daerah maupun luar negeri (Wawancara, Lalu Bakri, 04 Mei 2019)

Kondisi masyarakat Gegek setelah adanya pondok pesantren Ulil Al Baab NW Gegek menunjukan adanya peningkatan yang signifikan. Perubahan itupun menyentuh segala aspek kehidupan seperti pendidikan, perekonomian dan kegiatan-kegiatan 
keagamaan. Ini merupakan keuntungan bagi kehidupan masyarakat Gegek terbukti dengan adanya beberapa orang tua yang menyekolahkan anaknya di ponpes ini.

Banyak masyarakat Gegek yang antusias menyekolahkan anaknya di pondok pesantren Ulil Al Baab NW Gegek dikarenakan:

a. Biaya yang relatif murah dengan tetap menjaga kualitas pendidikan yang dapat menciptakan generasi-generasi islam penerus bangsa.

b. Sistem pendidikan dengan perpaduan agama dan modern sehingga masyarakat gegek berfikir bahwa alumni-alumni pondok pesantren Ulil Al Baab NW Gegek dapat menghadapi masa depan di era global dengan imtak dan iptek.

c. Jiwa sosial yang tinggi kepada masyarakat sekitar dari pimpinan pondok pesantren Ulil Al Baab NW Gegek sehingga menarik simpati masyarakat, seperti didirikannya lembaga LKSA dan Lembaga untuk orang tua jompo, dan membebaskan biaya santrisantri yang memang tidak mampu dari segi biaya untuk tetap belajar di Pondok Pesantren Ulil Al Baab NW Gegek.

Masalah etika berpakaian bagi kaum ibu dan remaja putri telah mengalami perubahan dan peningkatan kearah yang lebih baik. Sekarang kebanyakan para wanita disekitar lingkungan pesantren khususnya pada masyarakat Gegek selalu menggunakan busana tertutup dan memakai hijab. Hal ini merupakan awal perubahan menuju kehidupan yang lebih baik lagi. Proses perubahan secara bertahap merupakan hal yang biasa ditemui oleh para pembaharu. Islam pun ketika datang tidak serta merta diterima khalayak ramai, tapi membutuhkan proses yang cukup panjang. Sebagai contoh pada awal-awal berdirinya ponpes ini kebutuhan air dan pasilitas masih minim sehingga khusunya bagi laki-laki hal-hal seperti wudhu dan mandi pada setiap shalat harus berwuduk di kali. Seperti yang diutarkan oleh Kepala Dusun Gegek bahwa sebelum pondok pesantren memiliki fasilitas seperti ini banyak santriwan (santri laki-laki) pergi ke kali atau biasa disebut disini mbur untuk mandi, mencuci, dan lain-lain, karena di dalam pondok pesantren belum ada kamar mandi untuk laki-laki (Wawancara, Lalu Bakri, 04 Mei 2019).

Dengan sering adanya kegiatan keagamaan dalam pesantren masyarakat gegek terbiasa di perlihatkan aktivitas keagamaan yang dilakukan oleh pikah pondok ataupun santri, hal itu mempengaruhi peningkatan aktifitas ibadah mereka kepada Allah SWT. Apalagi dengan banyaknya masyarakat Gegek yang menyekolahkan anaknya di ponpes 
ini memberikan suasana baru bagi mereka, juga terciptanya budaya baru bagi masyarakat Gegek, yakni budaya salam seperti yang diterangkan oleh salsah satu guru bahwa:

Alhamdulillah dari segi budaya termasuk ada perubahan yang terjadi karena dibandingkan dari yang dulu agak jauh dari pedesaan atau perkotaan dan lebih lebih sekarang budaya itu sangat beda. Jika dikaitkan dengan santri bisa mengntrol budaya-budaya luar yang tidak sesuai dengan norma-norma yang keterkaitan dngan masyarakat dan budaya yang terciptka itu adalah budaya memberdayakan salam. Sebab dapat dijadikan panutan dan teladan karena bagi masyarakat dan bagi keluarganya khususnya (Wawancara, Saepudin, 04 Mei 2019).

Pimpinan Pondok Pesantren Ulil Al Baab NW Gegek yang berasal dari Gegek dapat lebih mudah mengajarkan ilmu-ilmu agama karena telah mengetahui karakteristik masyarakat tersebut. Semakin kita mengetahui karakteristik seseorang maka semakin mudah kita mencari jalan untuk dapat masuk kedalam kehidupan mereka. Namun sebaliknya semakin kita tidak mengenal adat istiadat mereka, maka semakin sulit kita menyampaikan da'wah yang diinginkan. Para wali-wali khusunya Walisongo di masanya dalam menyebarkan agama Islam mereka terlebih dahulu memahami adat dan kebiasaan masyarakat di mana tempat mereka akan berdakwah (Anita, 2014: 243-266).

Bagaimanapun juga pondok pesantren merupakan wadah untuk belajar dan mempraktekkan kegiatan-kegiatan ibadah. Semakin sering masyarakat diberikan pembelajaran dan kegiatan-kegiatan keagamaan, lambat laun perubahan yang terjadi di masyarakat akan semakin maju dan lebih baik lagi. Dari segi ekonomi setelah adanya ponpes ini keadaan masyarakat sangat membaik. Hal ini terbukti dari awalnya mereka bermata pencaharian bertani dan sebagian besar mereka menjadi TKI/TKW, kini sebagian dari mereka berdagang dan menjadi tenaga pengajar, buruh bangunan (dalam membangun pondok pesantren), dan menjual makanan di sekitar pondok pesantren ataupun dalam kawasan pondok pesantren.

Sebagaimana yang diuraikan di atas data-data yang diperoleh terutama datadata yang berkaitan dengan pengaruh pondok pesantren dapat dikatakan bahwa keadaan masyarakat sekitar pondok pesantren jauh lebih baik dibandingkan sebelum adanya pondok pesantren. Peningkatan perekonomian masyarakat sekita pondok pesantren khususnya masyarakat Gegek sangat signifikan, baik dari peningkatan penghasilan tidak tetap menjadi lebih baik, ada juga yang menjadi karyawan di pondok pesantren seperti, menjadi petugas kebersihan, tukang bangunan, p etugas memasak bagi para santri, dan menjadi tenaga pengajar. 
Budaya keagamaan masyarakat sekitar mengalami perubahan dan peningkatan baik dari kualitas keagamaan yang pada awalnya kurang memiliki daya tarik untuk diikuti menjadi mengalami gairah untuk mengikuti kegiatan tersebut, dan terciptanya budaya baru dalam masyarakat yakni budaya menebarkan "salam". Dalam hal pendidikan masyarakat di pondok pesantren khusunya masyarakat Gegek mengalami peningkatan yang signifikan, hal ini dapat dilihat dari banyaknya anak-anak sekitar pesantren khusunya masyarakat Gegek yang taraf pendidikannya rendah menjadi lebih baik terbukti dengan semakin banyaknya para orang tua yang menyekolahkan anak-anaknya baik itu ke sekolah umum ataupun sekolah agama di pondok pesantren. Mengenai keagamaan masyarakat Gegek banyak mengalami peningkatan pemahaman agama, dengan adanya pengajian yang diadakan dari pihak pesantren yang diadakan setiap harinya dan setiap bulannya. Setelah adanya pondok pesantren dari segi ibadah pada masyarakat telah mengalami penigkatan ini dapat dilihat dari masyarakat yang sering mengikuti ibadah shalat berjamaah dan mengikuti pengajian-pengajian.

Berdasarkan uraian di atas bahwa eksistensi pondok pesantren Uli Al Baab NW Gegek sangat besar kontribusi dalam meningkatkan kualitas hidup bagi masyarakat sekitar khususnya masyarakat Gegek dalam berbagai bidang, baik sosial kemasyarakat maupun sosial keagamaan, dan ekonomi. Dengan demikian tujuan-tujuan ponpes baik yang umum maupun yang khusus dapat tercapai dengan menjalin hubungan simbiosis mutualisme dengan masyarakat sekitar (Fuad, 2012), sehingga interaksi antara ponpes Gegek dengan masyarakat sekitar terjalin dengan kuat.

\section{Dampak Pondok Pesantren Ulil Al Baab NW Gegek Bagi Perkembangan Perekonomian Masyarakat Gegek}

Pondok pesantren Uli Al Baab NW Gegek berada di Dusun Gegek Desa Perian Kecamatan Montong Gading Kabupaten Lombok Timur. Pondok pesantren ini berada di wilayah terpencil. Akses sarana-prasarana menuju desa ini cukup sulit untuk dilalui. Hal ini sangat berpengaruh pada kehidupan ekonomi masyarakat. Masyarakat Dusun Gegek yang rata-rata berprofesi petani sebagai mata pencaharian utama, namun mereka tidak bisa berbuat banyak untuk mengembangkan pertaniannya. Padahal dusun Gegek mempunyai lahan pertanian yang sangat luas. Lahan pertanian ini merupakan potensi tersendiri yang dapat dikembangkan guna menaikkan taraf perekonomian warga. Hal ini 
dikarenakan masyarakat dusun Gegek masih menggunakan sistem pertanian yang belum tertata secara sistematis di samping masyarakat masih minim pengetahuan. Juga ada beberapa dari masyarakat menjadi TKI sebagi mata pencahariannya (Wawancara Asmayanti, 03 Mei 2019).

Pondok pesantren yang secara garis besar keberadaanya di daerah pedesaan pasti akan dihadapkan dengan fakta sosial, yakni keadaan dimana masyarakat disekitanya mengalami perekonomian yang masih berada di kelas menengah ke bawah. Oleh karena itu alangkah baiknya pondok pesantren memiliki andil dalam membangun ekonomi masyarakat sekitar (Yuliani, 2016; Aidi, 2012). Sekarang ini sering muncul anggapan bahwa agama dan ekonomi dua hal yang berbeda, jika kita berbicara tentang ekonomi maka tidak bisa kita gabungkan dengan membicarakan dengan agama, karena yang satu menunut keikhlasan yang biasanya diartikan sebagai bentuk ketidakberharapan terhadap keuntungan, sedangkan yang satu selalu dihubungkan dengan masalah keuangan, keuntungan, dan pamrih. Jika kita berbicara pesantren seolah-olah tidak ada hubungannya dengan masalah ekonomi, lebih-lebih jika kita membahasa masalah keagamaan yang lebih mendalam, padahal dua masalah ini adalah dua mata uang yang tidak bisa dipisahkan (Wawancara Hj. Raudah, 06 Mei 2019).

Secara umum fase awal berdirinya pondok pesantren mengacu pada pengembangan ilmu pendidikan keagamaan saja belum begitu memperhatikan bidang-bidang kemasyarakatan yang lainnya. Namun seiring berjalannya waktu pondok pesantren juga melebarkan sayapnya dengan melakukan gerakan sosial (yang lebih mengarah kepada segi perekonomian). Dengan demikian dapat dikatakan bahwa pondok pesantren di satu sisi berfungsi sebagai lembaga pendidikan berbasi agama Islam dan di sisi lain juga pondok pesantren menuju sebagai lembaga sosial kemasyarakatan. Pondok pesantren dikatakan sebagai lembaga sosial kemasyarakatan karena secara umum letaknya berada di tengah-tengah lingkungan masyarakat, sehingga pondok pesantren dituntut untuk bisa melakukan suatu kegiatan maupun pemberdayaan yang sifatnya membangun (Suyati, 2010). Berbagai macam kegiatan telah dilakukan oleh lembaga pondok pesantren seperti, mengadakan kegiatan kewirausahaan dengan membentuk koperasi untuk para santri.

Pondok pesantren bukan hanya berfungsi sebagai ladang untuk mencari rizki tetapi pondok pesantren juga sebagai awal dari perubahan kehidupan sekitar (Wahidah, 2015). Gegek adalah salah satu dusun yang tidak terlalu dilihat oleh pemerintah dari sekian 
dusun yang ada di lombok ini. Pondok pesantren ini adalah salah satu alasan dusun Gegek ini dilihatnya oleh pemerintah. Seperti yang dituturkan oleh salah satu narasumber menyatakan bahwa jika dilihat dari dulu sampai sekarang semenjak adanya pondok pesantren di dusun Gegek ini dilihat oleh pemerintah. Jika tempo dulu kita lihat dengan sekarang maka banyak sekali perkembangannya mulai dari infrastruktur yang terus diperbaiki (Wawancara, Zuliya Rahma, 03 Mei 2019).

Dinamika ekonomi masyarakat di sekitar pesantren sendiri terus berkembang atau dikembangkan, baik masyarakat yang hanya menitipkan barang dagangan di dalam pesantren, maupun masyarakat yang mendirikan usaha di sekitar pesantren mulai membentuk usaha toko, warung, dan tempat dagangan lainnya. Potensi ekonomi tumbuh dan berkembang cukup dinamis setidaknya berdasarkan hasil observasi langsung di lingkungan pondok pesantren. Selama mengamati usaha-usaha ekonomi yang ada dalam dan di luar pesantren ada beberapa unit usaha yang ada dan berkembang di dalam dan diluar pesantren. Berikut usaha-usaha yang ada dilingkungan pondok pesantren diantaranya:

1. Penyuplai dagang kecil ke dalam pesantren, karakteristik ini terdiri dari elemen masyarakat yang menitipkan barang dagangan mereka ke dalam pesantren atau warung-warung yang berada dalam lingkungan pesantren. Karakteristik ekonomi semacam ini biasanya dilakukan setiap hari, lebih-lebih saat pagi hari. Hal ini dilakukan untuk memenuhi kebutuhan santri sarapan pagi.

2. Mendirikan usaha permanen, karakteristik ini dilakukan oleh masyarakat sekitar pondok pesantren dengan cara mendirilam usaha dagang secara mandiri dan bersifat permanen, biasanya tempat usaha ini dibuka atau didirikan di dekat-dekat rumah mereka sendiri, karakter ekonomi semacam ini dilakukan dengan cara bermacammacam, ada toko, warung makanan dan lain sebagainya, usaha tersebut dianggap sebagai salah satu media untuk menggali keuntungan di sekitar pondok pesantren. Dengan objek dan konsumen yang sama, yaitu para santri Ulil Al Baab itu sendiri, yang berada di dalam lingkungan pesantren dan masyarakat yang berada sisekitar pondok pesantren (Observasi, 03 Mei 2019).

Ada beberapa keuntungan dan hambatan pengembangan ekonomi terhadap masyarakat sekitar. Berdasarkan informasi yang penulis temukan di lapangan, usaha dikembangkan oleh masyarakat sekitar pesantren sangat berarti bagi kehidupan mereka. 
Rata-rata informan mengaku bahwa usaha yang dikembangkan di sekitar pesantren tersebut menjadi tumpuan ekonomi keluarga mereka. Dengan unit usaha toko, warung, dan unit usaha yang lain menjadi satu-satunya penopang kehidupan mereka. Sementara bagi masyarakat sekitar yang menitipkan barang dagangan mereka didalam pesantren, selain ada yang mengakui sebagai satu-satunya sumber penghasilan, ada juga yang menyatakan hanya sebagai sampingan saja dari pekerjaan utama mereka sebagai petani.

Berdasarkan beraneka ragam bentuk jenis/usaha dalam melakukan pengembangan ekonomi yang ditemukan pada masyarakat sekitar pesantren Ulil Al Baab maka berbeda pula keuntungan dan hambatan yang mereka alami. Dimana bagi masyarakat yang bentuk usahanya tersebut bertumpu pada santri sebagai konsumennya (masyarakat sebagai suplier makanan), maka hambatannya dapat dilihat sebagai berikut yaitu:

a. Bisnis ini terbatas artinya masyarakat tidak dapat menjalankan bisnis ini secara terus menerus karena tergantung kepada santri, disaat pondok pesantren libur dan santri pada pulang maka bentuk pengembangan ekonomi seperti ini tidak dapat dilakukan, tentunya usaha masyarakat yang seperti ini tidak dapat diandalkan juga dapat gagal seumpa santri mulai berkurang

b. Keuntungan bagi masyarakat yang pengembangan ekonominya berbentuk usaha seperti ini tidak banyak menyita waktu. Perputaran uang yang cepat dan masyarakat dapat melakukan pekerjaan lainnya, seperti pergi ke sawah pengurus pertanian mereka.

c. Keuntungan dan hambatan diatas sekitar berbeda pula bagi masyarakat yang model pengembangan ekonominya berbentuk membuka warung makan dan warung jajanan dimana sifatnya permanen maka sebagai keuntungan bisnis ini tetap berjalan usaha tersebut tetap buka meskipun lagi liburan pondok pesantren, dan tidak bisa di pungkiri kalau lagi liburan pondok usaha mereka mengalamu penurunan pamasukan dan ini menjadi hambatan tersendiri bagi mereka, tetapi tidak langsung tutup karena konsumen mereka masyarakat umum tidak terbatas pada santri.

Indikator perubahan perekonomian yang dapat diketahui selain hal di atas adalah bahwa dengan adanya pondok pesantren, perubahan dalam kehidupan masyarakat tidak terjadi hanya pada aspek sosial, tetapi juga pada aspek ekonomi. Masyarakat yang semulanya hanya berpenghasilan pas-pasan dan banyak yang mencari peluang kerja di luar daerah maupun luar negeri kini memilih menetap di tempat/desanya masing-masing. Selain itu juga, tingkat perubahan ekonomi masyarakat dapat kita ketahui juga dengan 
adanya masyarakat yang mulai mengembangkan usaha-usaha lain selain bisnis perdagangan, seperti usaha pelayanan, dan jasa. Contohnya, pemuda-pemuda terpelajar/berpendidikan banyak membuka pendidikan nonformal yang ditujukan bagi para santri yang menginginkan atau memperdalam salah satu ilmu yang ditawarkan, misalnya kursus bahasa Inggris, bahasa Arab, komputer, menjahit, dan beberapa keahlian lainnya. Dalam bidang layanan, masyarakat mendirikan warung-warung internet yang bisa dimanfaatkan masyarakat, dan khususnya bagi para santri di ponpes ini.

Salah satu hal yang paling terlihat perubahannya di masyarakat adalah sistem mata pencaharian masyarakat sekitar. Yang semula masyarakat rata-rata adalah sebagai petani/pekebun kini sudah banyak menjadi pembisnis, baik dalam bidang pelayanan, jasa, maupun perdagangan produk kebutuhan sandang dan pangan. Hal ini mereka manfaatkan karena setelah adanya ponpes, sarana yang sebelumnya tidak dapat menunjang bisnis dan usaha mereka, kini sudah mulai teratasi. Sarana prasarana usaha seperti jaringan telekomunikasi, jalan raya sudah mulai diperbaiki. Sehingga usaha-usaha ekonomi mereka mendapatkan pendapatan yang banyak dan meningkatkan profit ekonomi mereka.

Dari beberapa penjelasan di atas pondok pesantren Ulil Al Baab NW Gegek sangat membantu dalam memajukan dan mengembangkan perekonomian masyarakat khususnya masyarakat Gegek, baik dalam bidang usaha dagang, pelayanan informasi, maupun kesehatan. Dapat dikatakan juga bahwa ponpes ini banyak menciptakan peluang usaha ekonomi bagi masyarakat desa sekitar yang sebelumnya hanya fokus pada satu usaha, selanjutnya berkembang menjalankan berbagai macam jens usaha, yang tentunya bukan hanya bermanfaat bagi para santri pondok pesantren, tetapi juga untuk masyarakat luar.

\section{Kesimpulan}

Pondok Pesantren Ulil Al Baab NW berada di Dusun Gegek Desa Perian Kecamatan Montong Gading Kabupaten Lombok Timur yang didirikan oleh TGH. Lalu Suparlan Ahmad pada tahun 1993. Pondok pesantren ini adalah lembaga pendidikan, sosial dan dakwah yang berada di bawah naungan salah satu organisasi terbesar di Provinsi Nusa Tenggara Barat yaitu organisasi Nahdlatul Wathan. Pondok pesantren ini didirikan oleh TGH. Lalu Suparlan pada tahun 1993 di Dusun Gegek. Pengaruh pondok pesantren Ulil Al Baab NW Gegek yang terhadap masyarakat dapat dikatakan memiliki 
dampak yang sangat besa. Hal itu bisa dilihat dari beberapa hal yakni masalah kebudayaan jika sebelumnya tidak ada kebudayaan yang sangat terlihat di dalam masyarakat, namun sekarang perbedaan itu bisa terlihat yakni terciptanya kebudayaan baru yaitu, budaya "salam". Dalam hal pendidikan masyarakat mengalami peningkatan yang sebelumnya mayarakat Gegek bisa dikategorikan sebagai masyarakat yang kurang perduli akan pendidikan menjadi sangat perduli akan pendidikan. Hal ini terbukti dengan semakin banyaknya para orang tua yang menyekolahkan anak-anaknya baik itu ke sekolah umum ataupun sekolah agama. Dalam hal keagamaan juga seperti itu, jika sebelumnya minat masyarakat rendah dalam beribadah namun sekarang minat mereka jauh lebih baik. Hal itu bisa dilihat dari masyarakatnya yang sering ikut andil dalam hal beribadah seperti, mengikuti solat berjamaah bersama santri dan mengikuti pengajian di setiap bulannya. Peningkatan perekonomian masyarakat sekitar pondok pesantren Ulil Al Baab NW Gegek sangat signifikan, baik dari peningkatan penghasilan yang sebelumnya bisa dikategorikan sangat kurang menjadi penghasilan yang tercukupi. Jika sebelumnya mereka hanya mengandalkan hasil pertanian, namun setelah adanya pondok pesantren mereka memiliki mata pencaharian baru misalnya membangun toko baju, warung makanan, dan usaha laundry.

\section{Daftar Rujukan}

Aidi, Junial (2012). Kota Santri kota Kajian Sosiologi Sebuah Kota di Lombok Timur. Yogyakarta: Pintal.

Anita, Dewi Evi. (2014). Walisongo: Mengislamkan Tanah Jawa Suatu Kajian Pustaka, Wahana Akademika, 1(2), 243-266.

Chusmeru, C., Masrukin, M., \& Pangestuti, S. (2017). Koperasi Pondok Pesantren sebagai Pemberdayaan Ekonomi Santri. Prosiding, 7(1).

Data Yayasan Pondok Pesantren Ulil Albab NW Gegek Tahun 2016.

Fuad, N. (2012). Pendidikan Berbasis Masyarakat di Pondok Pesantren. Jurnal Manajemen Pendidikan, 3(1).

Gunawan, Ary H. (1986). Kebijakan Kebijakan Pendidikan di Indonesia. Jakarta: Bina Aksara.

Hafidh, Z., \& Badrudin, B. (2018). Pesantren dan Kemandirian Perekonomian: Studi tentang Kewirausahaan di Pondok Pesantren Ar-Risalah Cijantung IV Ciamis. Manageria: Jurnal Manajemen Pendidikan Islam, 3(2), 257-267.

Hasil Observasi, 03 Mei 2019 
Muhakamurrohman, A. (2014). Pesantren: Santri, kiai, dan tradisi. IBDA: Jurnal Kajian Islam Dan Budaya, 12(2), 109-118.

Noor Habib dan Zuhdi Harfin. (2014). Visi Kebangsaan Religius: Refleksi Pemikiran dan Perjuangan Tuan Guru Kyai Haji Muhammad Zainuddin Abdul Madjid 1904-1997. Jakarta Timur: Pondok Pesantren Nahdatul Wathan Jakarta.

Profil Desa Perian Tahun 2016.

Qomar, Mujamil. (2007). Manajemen Pendidikan Islam: Strategi Baru Pengelolaan Lembaga Pendidikan Islam, Jakarta: Erlangga.

Reginald, A. R., \& Mawardi, I. (2014). Kewirausahaan Sosial Pada Pondok Pesantren Sidogiri Pasuruan. Jurnal Ekonomi Syariah Teori dan Terapan, 1(5), 333-345.

Rifa'i Muhammad. (2011). Sejarah Pendidikan Nasiona dari Masa Klasik Hingga Modern. Jogjakarta: Ar-Ruzz Media.

Rohmatun, R. Sosial Ekonomi Masyarakat Grenjeng (Studi Kasus Dampak Keberadaan Pondok Pesantren Al Madinah pada Kehidupan Sosial Ekonomi Masyarakat Desa Grenjeng Kecamatan Nogosari Kabupaten Boyolali Tahun 2011). Skripsi. Surakarta: Universitas Sebelas Maret.

Sugandi, A., Tanjung, H. B., \& Rusli, R. K. (2017). Peran Pondok Pesantren (Ponpes) Modern Dalam Pemberdayaan Ekonomi Masyarakat. Tadbir Muwahhid, 1(2), 99115.

Suharto, Edi. (2005). Membangun Masyarakat Memberdayakan Rakyat Kajian Strategis Pembangunan Kesejahteraan Sosial dan Pekerjaan Sosial. Bandung: Refika Aditama.

Sulthon dan Khusnurdilo. (2008). Manajemen Pondok Pesantren. Jakarta: Diva Pustaka.

Suyati, S. (2010). Strategi Dakwah Dalam Pengembangan Sumber Daya Pesantren (Studi Kasus di Pondok Pesantren Raudlatut Tholibin Rembang). Skripsi. Semarang: IAIN Walisongo).

Syafe'i, I. (2017). Pondok Pesantren: Lembaga Pendidikan Pembentukan Karakter. AlTadzkiyyah: Jurnal Pendidikan Islam, 8(1), 61-82.

Syarbani, H. (2012). Analisis pengaruh partisipasi santri komitmen dan kemampuan berinovasi terhadap kinerja koperasi pondok pesantren di kota semarang. Economica: Jurnal Ekonomi Islam, 2(2), 27-42.

Ulum, A. Y. M. (2018). Sejarah Perkembangan Pondok Pesantren Musatabihul Ulum Desa Dawung Kecamatan Ringinerjo Kabupaten Kediri. Jurnal Simki Pedagogia, 2(2).

Wahidah, E. Y. (2015). Studi Implementasi Tradisionalisasi dan Modernisasi Pendidikan di Pondok Pesantren. Jurnal Muaddib, 5(2).

Wawancara Asmayanti, 03 Mei 2019.

Wawancara Hj. Raudah, 06 Mei 2019.

Wawancara, H. L. Budi Karyawan, 2 Mei 2019. 
Jurnal Humanitas

Vol. 6 No. 1, Desember 2019, hal. 76-98

Wawancara, Lalu Bakri, 04 Mei 2019.

Wawancara, Saepudin, 3 Mei 2019.

Wawancara, TGH. Lalu Suparlan, 5 Mei 2019.

Wawancara, Zuliya Rahma, 03 Mei 2019.

Yuliani, E. (2016). Pengembangan Masyarakat Pedesaan Berbasis Pesantren. Lembaran Masyarakat: Jurnal Pengembangan Masyarakat Islam, 2(2), 69-96.

Zaenurrosyid, A. (2018). Pengaruh Pondok Pesantren Terhadap Kehidupan Sosial Masyarakat Desa Kajen Kec. Margoyoso Kab. Pati. Islamic Review: Jurnal Riset dan Kajian Keislaman, 7(1), 55-71. 